\title{
Obesity Does Not Imply Poor Outcomes in Asians after Total Knee Arthroplasty
}

\author{
Hamid Rahmatullah Bin Abd Razak MBBS, \\ Hwei Chi Chong BSc, Andrew Hwee Chye Tan MBBS, FRCS (Orth)
}

Received: 15 August 2012/ Accepted: 14 November 2012/Published online: 5 December 2012

(C) The Association of Bone and Joint Surgeons \& 2012

\begin{abstract}
Background In Asia, obesity has reached epidemic proportions and physicians are likely to face a burden of obesity-related disorders, of which osteoarthritis of the knee is one. However, it is unclear whether obesity affects improvement of conventional TKAs in Asian patients.

Purpose We therefore asked whether obese patients with a BMI of $30 \mathrm{~kg} / \mathrm{m}^{2}$ or greater would have worse ROM and function after TKA compared with their nonobese counterparts and whether they would have less improvement preoperatively to postoperatively.
\end{abstract}

Each author certifies that he or she, or a member of his or her immediate family, has no funding or commercial associations (eg, consultancies, stock ownership, equity interest, patent/licensing arrangements, etc) that might pose a conflict of interest in connection with the submitted article.

All ICMJE Conflict of Interest Forms for authors and Clinical Orthopaedics and Related Research editors and board members are on file with the publication and can be viewed on request. Clinical Orthopaedics and Related Research neither advocates nor endorses the use of any treatment, drug, or device. Readers are encouraged to always seek additional information, including FDA-approval status, of any drug or device prior to clinical use. Each author certifies that his or her institution approved or waived approval for the human protocol for this investigation and that all investigations were conducted in conformity with ethical principles of research.

H. R. Bin Abd Razak ( $₫)$, A. H. C. Tan

Department of Orthopaedic Surgery, Singapore General

Hospital, Outram Road, Singapore 169608, Singapore

e-mail: hamidrazak@gmail.com

\section{H. C. Chong}

Department of Physiotherapy, Singapore General Hospital,

Outram Road, Singapore 169608, Singapore
Methods We retrospectively reviewed 369 patients who underwent TKAs from 2006 to 2010 . We stratified patients into four groups: (1) 98 patients with BMIs less than $25 \mathrm{~kg} / \mathrm{m}^{2}$; (2) 158 patients with BMIs between $25 \mathrm{~kg} / \mathrm{m}^{2}$ and $29.9 \mathrm{~kg} / \mathrm{m}^{2}$; (3) 87 patients with BMIs between $30 \mathrm{~kg} /$ $\mathrm{m}^{2}$ and $34.9 \mathrm{~kg} / \mathrm{m}^{2}$; and (4) 26 patients with BMIs greater than $35 \mathrm{~kg} / \mathrm{m}^{2}$. We then compared ROM, function score, Knee Society score, Oxford Knee Questionnaire, and SF36 questionnaire ${ }^{\circledR}$ across the four groups at 6- and 12-month followups.

Results At the 6-month followup, we found a difference only in the ROM. At the 2-year followup, there were no differences in any functional scores across the four groups. Severely obese patients had greater improvement in postoperative ROM than the other groups but did not have any greater improvement in function.

Conclusion BMI had little clinical impact on short-term outcomes of conventional TKAs in Asian patients. The data suggest that BMI should not be used as a major determinant to exclude obese patients from surgery with the presumption of poorer outcomes.

Level of Evidence Level III, therapeutic study. See the Guideline for Authors for a complete description of levels of evidence.

\section{Introduction}

TKA is one of the most common elective surgical procedures performed to alleviate pain and disability associated with knee osteoarthritis (OA) [15]. Obese patients are at increased risk for the development of knee OA [4, 12, 29], possibly owing to an increased cumulative load history. Obesity reportedly is associated with various metabolic 
disturbances that could result in systemic risk factors for OA [4]. Gillespie and Porteous [12] commented, "While increased risk of complications and early implant failure has been shown by some studies in the morbidly obese, there is no definite cut-off in Body Mass Index which accurately separates high-risk from low-risk individuals, although there is evidence that heavier patients are at greater risk."

Obesity has reached epidemic proportions in Asia and as a result there is a potentially large burden of obesity-related disorders [22]. Obesity generally is defined by the BMI, which correlates with total body fat and is also a harbinger of cardiovascular risks [5, 6]. According to the WHO, a patient with a BMI of $30 \mathrm{~kg} / \mathrm{m}^{2}$ or greater is considered obese [32]. The risk of having obesity-related complications after TKA increases after BMI reaches $25 \mathrm{~kg} / \mathrm{m}^{2}$ [26]. However, in the Asian population the risks reportedly increase with a BMI greater than $23 \mathrm{~kg} / \mathrm{m}^{2}$ [8]. This largely has been attributed to the higher fat mass for a given BMI in the Asian population compared with the white population [17]. The impact of obesity on the outcomes of TKA is reportedly variable [28]. Increased body weight intuitively would be expected to lead to a poorer outcome as a result of the greater biomechanical forces generated on the prosthetic components and the surrounding bone. Distinction between weight and BMI, however, is important, as the former is an absolute measure, while the latter is a relative one. Whereas body weight may be a predictor of poor outcomes, BMI may not [23]. The lower activity level typically observed in obese patients may offset the harmful effects of increased biomechanical forces on the boneprosthesis interface.

Some studies $[11,30]$ show a higher prevalence of knee OA in obese subgroups of Asian patients. There have been several papers $[9,14,27]$ to date discussing the impact of obesity on postoperative outcomes after TKAs in Western patients. Given the fact that obesity-related complications occur at a lower BMI in Asian as compared with the Western population, Asia could see a greater number of obese patients consulting orthopaedic surgeons for TKAs.

Although Western studies $[12,14]$ show the deleterious effects of obesity on postoperative outcomes after conventional TKAs, studies on Asian patients are few and inconclusive. With the advent of globalization and migrant communities throughout the world, it is important surgeons know the peculiar characteristics of a patient from a particular community so that the ideas, concerns, and expectations of the patient are addressed.

We asked whether obese Asian patients with a BMI of $30 \mathrm{~kg} / \mathrm{m}^{2}$ or greater would have worse ROM and function after TKA compared with their nonobese counterparts and whether they would have less improvement preoperatively to postoperatively.

\section{Patients and Methods}

We retrospectively reviewed 387 patients who underwent elective TKAs from January 2006 to May 2009. All had the same surgical technique and postoperative care. We excluded 18 patients for one of two reasons: symptomatic $\mathrm{OA}$ in the contralateral knee (defined as self-reported knee pain greater than 4 on a 10-point, verbal analog scale) or other lower extremity orthopaedic conditions or neurologic impairments that limited function. These exclusions left 369 patients $(95 \%)$ for review. Our institutional review board waived approval for this study.

All patients underwent unilateral posterior-stabilized TKAs by one surgeon (HCT). All had tourniquets applied to the surgically treated limbs throughout the course of the surgeries. TKAs were performed in standard fashion for all patients. The medial parapatellar approach was used for patients with varus $\mathrm{OA}$, and the lateral parapatellar approach was used for patients with valgus knees with OA. All patients in this study received a standard tibial implant. Patellar resurfacing was not performed in all patients. Drains were inserted for all patients and removed on either Postoperative Day 2 or when the drainage was less than $70 \mathrm{~mL}$, whichever occurred earlier.

All patients received standardized postoperative care, which included appropriate oral and parenteral analgesia, mechanical calf pumps, continuous passive motion from the first postoperative day, and daily inpatient physiotherapy assessments. All patients began ambulation on the second postoperative day. None of the patients received oral chemoprophylaxis for deep vein thrombosis and pulmonary embolus as our previous study on Asian patients undergoing conventional TKAs without chemoprophylaxis showed a low incidence of venous thromboembolic events [3]. On discharge, patients were followed up at the specialist outpatient clinic at 1 month, 6 months, 1 year, and 2 years. At each visit, the patient reported the pain score and any other concerns they had to the surgeon. The surgeon also examined the knee for any signs of wound or joint infection. Detailed review by the physiotherapist, as outlined below, was conducted at 6 months and 2 years after TKA. Radiographs of the knee also were obtained in the immediate postoperative period and at the 1-year followup.

Heights and weights of the patients noted at hospital admission were extracted from the standardized medical case notes. Health service utilization data collected during the 6 months after discharge were extracted from the local healthcare databases. These data included length of stay (LOS) and readmission to Singapore hospitals. At the 6-month and 2-year followups a physiotherapist determined ROM of the surgically treated knee using a goniometer; we also obtained Knee Society scores [13], 
SF-36 ${ }^{\circledR}$ (The Medical Outcomes Trust, Hanover, NH, USA) [31], and Oxford Knee Score [7]. There were no missing data with respect to the demographic details and the functional outcomes for all patients in our study who returned for the required followups.

Definitions of obesity have varied widely, and no standard definition exists $[1,6]$. We used the BMI classification as defined by the WHO: underweight $\left(<18.5 \mathrm{~kg} / \mathrm{m}^{2}\right)$, normal (18.5-24.9 kg/m ${ }^{2}$ ), overweight $\left(25.0-29.9 \mathrm{~kg} / \mathrm{m}^{2}\right)$, and obesity Class $1\left(30.0-34.9 \mathrm{~kg} / \mathrm{m}^{2}\right)$, Class $2(35.0-$ $\left.39.9 \mathrm{~kg} / \mathrm{m}^{2}\right)$, and Class $3\left(\geq 40.0 \mathrm{~kg} / \mathrm{m}^{2}\right)$. Owing to the small samples of Classes 2 and 3, these two groups were classified as one group in our analysis. Based on the above classifications, four BMI-dependent stratifications then were created: (1) normal $\left(<25.0 \mathrm{~kg} / \mathrm{m}^{2}\right)$; (2) overweight $\left(25.0-29.9 \mathrm{~kg} / \mathrm{m}^{2}\right)$; (3) obese $\left(30.0-34.9 \mathrm{~kg} / \mathrm{m}^{2}\right)$; and (4) severely obese $\left(\geq 35.0 \mathrm{~kg} / \mathrm{m}^{2}\right)$. Among the 369 patients, 98 had normal BMIs, 158 were overweight, 87 were obese, and 26 were severely obese. Patients in the obese and severely obese groups were younger $(\mathrm{p}<0.001)$, had greater prevalence of cardiovascular disease, diabetes mellitus $(\mathrm{p}<0.001)$, and a higher mean number of comorbidities $(\mathrm{p}<0.001)$ as compared with their nonobese counterparts (Table 1). Otherwise, we identified no differences in the gender proportions, LOS, and discharge locations from acute care. Preoperatively, patients in the severely obese group had lower ROM (Table 2) as compared with the rest $(\mathrm{p}<0.001)$.

ANOVA and the chi-square test were used to compare means and proportions respectively across the four groups. All statistical analyses were performed using Statistical Package for the Social Sciences (SPSS) Version $17\left(\right.$ IBM $^{\circledR}$ SPSS Statistics, Armonk, NY, USA).

\section{Results}

At the 6-month followup severely obese patients had a lower $(\mathrm{p}=0.006)$ mean ROM compared with patients in the other three groups (Table 3). However, at the 2-year followup there was no difference in the ROM across the four groups. We observed no differences in outcome scores among the four groups at 6 months and 2 years.

The severely obese group had greater improvement from baseline $(p=0.004)$ in postoperative ROM (Table 4), although there were no differences in improvement in outcome scores across the four groups.

Table 1. Patient characteristics

\begin{tabular}{|c|c|c|c|c|c|}
\hline Characteristics & $\begin{array}{l}\text { Normal group } \\
\left(\mathrm{BMI}<25 \mathrm{~kg} / \mathrm{m}^{2} ;\right. \\
\mathrm{n}=98)\end{array}$ & $\begin{array}{l}\text { Overweight group } \\
\left(\mathrm{BMI}=25-29.9 \mathrm{~kg} / \mathrm{m}^{2}\right. \\
\mathrm{n}=158)\end{array}$ & $\begin{array}{l}\text { Obese group } \\
\left(\mathrm{BMI}=30-34.9 \mathrm{~kg} / \mathrm{m}^{2}\right. \\
\mathrm{n}=87)\end{array}$ & $\begin{array}{l}\text { Severely obese group } \\
\left(\mathrm{BMI} \geq 35 \mathrm{~kg} / \mathrm{m}^{2} ;\right. \\
\mathrm{n}=26)\end{array}$ & $\mathrm{p}$ values \\
\hline \multicolumn{6}{|l|}{ Demographics } \\
\hline $\begin{array}{l}\text { Mean age in years } \\
\text { (range) }\end{array}$ & $67(42-83)$ & $67(51-83)$ & $63(50-81)$ & $63(51-76)$ & $<0.001$ \\
\hline Gender: female (\%) & $77(79)$ & $123(78)$ & $73(84)$ & $23(88)$ & 0.946 \\
\hline $\begin{array}{l}\text { Mean BMI in } \mathrm{kg} / \mathrm{m}^{2} \\
\text { (range) }\end{array}$ & $22.9(17.9-24.9)$ & $27.5(25.0-29.9)$ & $32.1(30.0-34.7)$ & $38.9(35.2-51.3)$ & $<0.001$ \\
\hline $\begin{array}{l}\text { Mean height in } \mathrm{m} \\
\text { (range) }\end{array}$ & $1.56(1.48-1.67)$ & $1.54(1.43-1.69)$ & $1.53(1.42-1.71)$ & $1.53(1.46-1.70)$ & 0.113 \\
\hline \multicolumn{6}{|l|}{ Medical status } \\
\hline $\begin{array}{l}\text { Primary diagnosis, } \\
\text { OA }(\%)\end{array}$ & $97(99)$ & $155(98)$ & $86(99)$ & $26(100)$ & 0.990 \\
\hline $\begin{array}{l}\text { Primary diagnosis, } \\
\text { inflammatory arthritis } \\
(\%)\end{array}$ & $1(1)$ & $3(2)$ & $1(1)$ & $0(0)$ & 0.6823 \\
\hline $\begin{array}{l}\text { Cardiovascular disease } \\
(\%)\end{array}$ & $21(21)$ & $38(24)$ & $34(39)$ & $18(69)$ & $<0.001$ \\
\hline Diabetes mellitus (\%) & $18(18)$ & $32(20)$ & $36(41)$ & $20(77)$ & $<0.001$ \\
\hline $\begin{array}{l}\text { Mean number of } \\
\text { comorbidities } \\
( \pm \mathrm{SD})\end{array}$ & $2.2( \pm 1.3)$ & $2.4( \pm 1.5)$ & $3.1( \pm 2.2)$ & $3.3( \pm 2.3)$ & $<0.001$ \\
\hline \multicolumn{6}{|c|}{ Healthcare services utilization } \\
\hline $\begin{array}{l}\text { Hospital LOS (days) } \\
\quad( \pm \mathrm{SD})\end{array}$ & $5.7( \pm 2.5)$ & $5.0( \pm 2.0)$ & $5.0( \pm 2.0)$ & $5.8( \pm 2.3)$ & 0.013 \\
\hline Discharge to home $(\%)$ & $85(87)$ & $136(86)$ & $67(77)$ & $14(54)$ & 0.332 \\
\hline
\end{tabular}

$\mathrm{OA}=$ osteoarthritis; LOS = length of stay. 
Table 2. Preoperative ranges of motion and outcome scores

\begin{tabular}{|c|c|c|c|c|c|}
\hline Variable & $\begin{array}{l}\text { Normal group } \\
\left(\mathrm{BMI}<25 \mathrm{~kg} / \mathrm{m}^{2} ;\right. \\
\mathrm{n}=98)\end{array}$ & $\begin{array}{l}\text { Overweight group } \\
\left(\mathrm{BMI}=25-29.9 \mathrm{~kg} / \mathrm{m}^{2}\right. \\
\mathrm{n}=158)\end{array}$ & $\begin{array}{l}\text { Obese group } \\
\left(\mathrm{BMI}=30-34.9 \mathrm{~kg} / \mathrm{m}^{2}\right. \\
\mathrm{n}=87)\end{array}$ & $\begin{array}{l}\text { Severely obese group } \\
\left(\mathrm{BMI} \geq 35 \mathrm{~kg} / \mathrm{m}^{2}\right. \\
\mathrm{n}=26)\end{array}$ & $\mathrm{p}$ value \\
\hline Mean ROM $\left(^{\circ}\right)$ & $119(86-155)$ & $119(77-155)$ & $116(71-150)$ & $100(60-125)$ & $<0.001$ \\
\hline $\begin{array}{l}\text { Mean Knee Society } \\
\text { knee score (range) }\end{array}$ & $33(0-91)$ & $36(0-83)$ & $33(0-69)$ & $29(0-74)$ & 0.251 \\
\hline $\begin{array}{l}\text { Mean Knee Society } \\
\text { function score } \\
\text { (range) }\end{array}$ & $51(0-91)$ & $52(0-100)$ & $51(0-90)$ & $46(20-80)$ & 0.590 \\
\hline $\begin{array}{l}\text { Mean Oxford Knee } \\
\text { Questionnaire score } \\
\text { (range) }\end{array}$ & $36(17-52)$ & $36(15-59)$ & $37(22-57)$ & $39(22-52)$ & 0.090 \\
\hline $\begin{array}{l}\text { Mean SF-36 Physical } \\
\text { Component score } \\
\text { (range) }\end{array}$ & $32(10-59)$ & $32(12-58)$ & $30(12-54)$ & $27(9-57)$ & 0.198 \\
\hline $\begin{array}{l}\text { Mean SF-36 Mental } \\
\text { Component score } \\
\text { (range) }\end{array}$ & $49(19-71)$ & $50(27-72)$ & $51(23-71)$ & $50(23-70)$ & 0.745 \\
\hline
\end{tabular}

Table 3. Postoperative ranges of motion and outcome scores

\begin{tabular}{|c|c|c|c|c|c|}
\hline Variable & $\begin{array}{l}\text { Normal group } \\
\left(\mathrm{BMI}<25 \mathrm{~kg} / \mathrm{m}^{2} ;\right. \\
\mathrm{n}=98)\end{array}$ & $\begin{array}{l}\text { Overweight group } \\
\left(\mathrm{BMI}=25-29.9 \mathrm{~kg} / \mathrm{m}^{2}\right. \\
\mathrm{n}=158)\end{array}$ & $\begin{array}{l}\text { Obese group } \\
\left(\mathrm{BMI}=30-34.9 \mathrm{~kg} / \mathrm{m}^{2}\right. \\
\mathrm{n}=87)\end{array}$ & $\begin{array}{l}\text { Severely obese group } \\
\left(\mathrm{BMI} \geq 35 \mathrm{~kg} / \mathrm{m}^{2}\right. \\
\mathrm{n}=26)\end{array}$ & $\mathrm{p}$ value \\
\hline \multicolumn{6}{|c|}{ Mean ROM $\left(^{\circ}\right)$} \\
\hline 6 months & $112(40-140)$ & $116(65-144)$ & $113(68-140)$ & $105(85-129)$ & 0.006 \\
\hline 2 years & $118(85-145)$ & $119(82-146)$ & $116(79-150)$ & $110(95-130)$ & 0.063 \\
\hline \multicolumn{6}{|c|}{ Mean Knee Society knee score (range) } \\
\hline 6 months & $80(29-99)$ & $80(29-100)$ & $80(18-100)$ & $76(47-94)$ & 0.676 \\
\hline 2 years & $83(37-100)$ & $85(30-100)$ & $85(20-100)$ & $82(49-98)$ & 0.542 \\
\hline \multicolumn{6}{|c|}{ Mean Knee Society function score (range) } \\
\hline 6 months & $66(34-100)$ & $66(35-100)$ & $64(22-100)$ & $55(35-90)$ & 0.066 \\
\hline 2 years & $71(10-100)$ & $71(5-100)$ & $67(25-100)$ & $65(40-100)$ & 0.148 \\
\hline \multicolumn{6}{|c|}{ Mean Oxford Knee Questionnaire score (range) } \\
\hline 6 months & $21(12-46)$ & $21(12-47)$ & $22(13-52)$ & $24(15-44)$ & 0.508 \\
\hline 2 years & $19(12-52)$ & $19(12-46)$ & $20(12-55)$ & $20(12-42)$ & 0.761 \\
\hline \multicolumn{6}{|c|}{ Mean SF-36 Physical Component score (range) } \\
\hline 6 months & $45(11-61)$ & $43(13-64)$ & $43(12-60)$ & $42(23-61)$ & 0.666 \\
\hline 2 years & $49(15-62)$ & $49(16-61)$ & $48(16-63)$ & $44(27-61)$ & 0.138 \\
\hline \multicolumn{6}{|c|}{ Mean SF-36 Mental Component score (range) } \\
\hline 6 months & $54(22-71)$ & $55(14-75)$ & $53(24-70)$ & $52(23-69)$ & 0.362 \\
\hline 2 years & $54(17-70)$ & $55(24-73)$ & $53(20-70)$ & $56(40-67)$ & 0.547 \\
\hline
\end{tabular}

\section{Discussion}

Obesity has reached epidemic proportions in Asia and as a result, the continent faces a grave burden of obesity-related disorders [22]. The risks of acquiring obesity-related disorders, of which OA of the knee is one, in the Asian population increase with a BMI greater than $23 \mathrm{~kg} / \mathrm{m}^{2}$ [8]. This could mean that the orthopaedic surgeon could be seeing a greater number of obese Asian patients with OA of the knee. Although there are Western studies [12, 14] that clearly show the deleterious effects of obesity on postoperative outcomes after conventional TKAs, studies of Asian patients are few and inconclusive. With the advent of globalization and migrant communities throughout the world, it is imperative that the surgeon knows the peculiar characteristics of a patient from a particular community so that the ideas, concerns, and expectations of the patient are addressed. We therefore asked whether obese patients with 
Table 4. Mean change in scores from preoperative to followup at 2 years

\begin{tabular}{|c|c|c|c|c|c|}
\hline Variable & $\begin{array}{l}\text { Normal group } \\
(\mathrm{n}=98)\end{array}$ & $\begin{array}{l}\text { Overweight group } \\
(\mathrm{n}=158)\end{array}$ & Obese group $(\mathrm{n}=87)$ & $\begin{array}{l}\text { Severely obese } \\
\text { group }(n=26)\end{array}$ & $\mathrm{p}$ value \\
\hline Mean change in $\mathrm{ROM}\left(^{\circ}\right)$ & -2 & -1 & -1 & +10 & 0.004 \\
\hline Mean change in Knee Society knee score & +51 & +49 & +52 & +53 & 0.684 \\
\hline $\begin{array}{l}\text { Mean change in Knee Society } \\
\text { function score }\end{array}$ & +20 & +19 & +16 & +19 & 0.498 \\
\hline $\begin{array}{l}\text { Mean change in Oxford Knee } \\
\text { Questionnaire score }\end{array}$ & +17 & +17 & +18 & +19 & 0.455 \\
\hline $\begin{array}{l}\text { Mean change in SF-36 Physical } \\
\text { Component score }\end{array}$ & +17 & +17 & +18 & +16 & 0.950 \\
\hline $\begin{array}{l}\text { Mean change in SF-36 Mental } \\
\text { Component score }\end{array}$ & +4 & +4 & +2 & +6 & 0.499 \\
\hline
\end{tabular}

a BMI of $30 \mathrm{~kg} / \mathrm{m}^{2}$ or greater would have worse ROM and function after TKA compared with their nonobese counterparts and whether they would have less improvement preoperatively to postoperatively.

There were limitations to our study. First, we did not have a full range of obese patients to evaluate and match. Therefore, statistical comparison across the four groups may have been skewed. However, this also may be reflective of the distribution of obesity in the local population or reflect referral bias for an elective TKA. Second, we examined obesity only at the time of surgery and did not evaluate it with time. Patients may have lost weight and thus moved from one stratification to another. This obviously would affect the accuracy of our results. However, there is enough in the literature $[10,16]$ to suggest that BMIs and activity levels change little during long-term rehabilitation after TKAs. With our study evaluating shortterm outcomes, we believe that there would be no major impact on our results from this limitation. Third, effects of confounding are inevitable in a retrospective study. Multivariate analysis to control for potentially confounding factors was limited owing to the small numbers in our study. Fourth, we did not report complications and cannot comment on this issue. However, several studies [2, 14, 19, 21] have reported obese patients had a higher number of perioperative complications.

We found obese patients with a BMI of $30 \mathrm{~kg} / \mathrm{m}^{2}$ or greater did not have worse ROM and function after TKA compared with their nonobese counterparts at 2 years of followup. This suggests obesity does not imply poorer function in the Asian population, at least in the short-term. Our findings may be surprising considering that many orthopaedic surgeons hesitate to operate on obese patients who are prone to higher risks of component failures and worse outcomes [2, 22]. Several recent studies [9, 10, 14, 27] have examined the impact of obesity on function of TKA (Table 5). Although some authors reported no differences in the function between nonobese and obese patients during short-term and long-term followups [9, 27], others have reported that severely obese patients had poorer function [10, 18]. Unlike Spicer et al. [24] who reported poorer preoperative scores with obese patients, our patients had similar preoperative outcome scores, the only exception being that the severely obese patients had poorer ROM. Concurring with Dewan et al. [9] and Stevens-Lapsley et al. [27], we did not find that BMI negatively influenced ROM or function after conventional TKA. Järvenpää et al. [14] prospectively studied 100 patients undergoing TKAs and compared ROM and function between two BMI-stratified groups. They found obese patients had worse ROM at 3 months compared with nonobese patients, echoing our ROM findings at 6 months. Although they concluded that obesity may impair the early outcomes of TKA, function was essentially similar between the two groups as in our study. They did find, however, that the obese patients had a higher number of perioperative complications, as did other authors $[2,19$, 21]. Nunez et al. [19] evaluated health-related quality of life preoperatively and at 1-year followups in severe and morbidly obese patients with knee OA and in a control group of nonobese patients undergoing TKAs. They found no differences in the outcome scores between the two groups.

We found patients in our severely obese group had gained a mean of $10^{\circ}$ in ROM, a stark contrast to the change in ROM noted in the other groups who lost a few degrees of ROM compared with their preoperative ROM. This was surprising as obese patients would be assumed to have a greater degree of difficulty with postoperative rehabilitation and therefore poorer improvement in their ROM. However, an improvement in ROM in a patient group with a poorer preoperative ROM is a trend that has been reported in the literature [20]. Parsley et al. [20] found patients with limited ROM preoperatively had an 
Table 5. Comparison of the literature

\begin{tabular}{|c|c|c|c|c|c|c|c|}
\hline Studies & $\begin{array}{l}\text { Number of } \\
\text { patients }\end{array}$ & Groups & $\begin{array}{l}\text { Preoperative ROM/ } \\
\text { degrees }\end{array}$ & $\begin{array}{l}\text { Postoperative } \\
\text { ROM/degrees }\end{array}$ & $\begin{array}{l}\text { Preoperative } \\
\text { outcome score }\end{array}$ & $\begin{array}{l}\text { Postoperative } \\
\text { outcome score }\end{array}$ & $\begin{array}{l}\text { Mean } \\
\text { followup }\end{array}$ \\
\hline $\begin{array}{l}\text { Dewan et al. } \\
\text { [9] }\end{array}$ & 220 & 3 & $\begin{array}{l}\text { Overweight: } 112 \pm 2 \\
\text { Obese: } 112 \pm 2 \\
\text { Morbidly obese: } \\
\quad 99 \pm 3 \\
\text { p value } 0.651\end{array}$ & $\begin{array}{l}\text { Overweight: } 123 \pm 1 \\
\text { Obese: } 120 \pm 1 \\
\text { Morbidly obese: } 68 \pm 4 \\
\text { p value } 0.248\end{array}$ & \multicolumn{2}{|c|}{$\begin{array}{l}\text { BMI did not adversely affect the } \\
\text { functional performance as measured } \\
\text { by the Knee Society knee score } \\
\text { (p value } 0.248 \text { ) }\end{array}$} & 5 years \\
\hline $\begin{array}{l}\text { Järvenpää } \\
\text { et al. [14] }\end{array}$ & 100 & 2 & Not available & $\begin{array}{l}\text { Nonobese: } 118 \\
\quad(115-122) \\
\text { Obese: } 110(106-113) \\
\text { p value } 0.001\end{array}$ & \multicolumn{2}{|c|}{$\begin{array}{l}\text { BMI did not adversely affect the } \\
\text { functional performance as measured } \\
\text { by the TUG (p value } 0.28 \text { ) and } \\
\text { walking distance (p value } 0.096 \text { ). }\end{array}$} & 3 months \\
\hline $\begin{array}{l}\text { Stevens-Lapsley } \\
\text { et al. [27] }\end{array}$ & 140 & 1 & Not studied & Not studied & \multicolumn{2}{|c|}{$\begin{array}{l}\text { BMI did not adversely affect the } \\
\text { functional performance as measured } \\
\text { by the TUG, SCT, and } 6 \text { MWT. } \\
\text { Significant F change: } 0.247\end{array}$} & 6 months \\
\hline Current Study & 369 & 4 & $\begin{array}{l}\text { Normal: } 119(86-155) \\
\text { Overweight: } 119 \\
\quad(77-155) \\
\text { Obese: } 116(71-150) \\
\text { Severely obese: } 100 \\
\quad(60-125) \\
\text { p value }<0.001\end{array}$ & $\begin{array}{l}\text { Normal: } 118(85-145) \\
\text { Overweight: } 119 \\
\quad(82-146) \\
\text { Obese: } 116(79-150) \\
\text { Severely obese: } 100 \\
\quad(95-130) \\
\text { p value } 0.0626\end{array}$ & \multicolumn{2}{|c|}{$\begin{array}{l}\text { BMI did not adversely affect the } \\
\text { outcomes scores as measured by the } \\
\text { Knee Society score ( } \mathrm{p} \text { value } 0.5422 \text { ), } \\
\text { function score ( } \mathrm{p} \text { value } 0.1479 \text { ), } \\
\text { Oxford Knee Questionnaire ( } \mathrm{p} \text { value } \\
0.7612 \text { ), and SF-36 physical ( } \mathrm{p} \text { value } \\
0.1384 \text { ) and mental component } \\
\text { ( } \mathrm{p} \text { value } 0.5467 \text { ) scores. }\end{array}$} & 2 years \\
\hline
\end{tabular}

$\mathrm{TUG}=$ timed up and go test; $\mathrm{SCT}=$ stair climbing test; $6 \mathrm{MWT}=6$-minute walk test.

improvement in ROM postoperatively. By contrast, patients with greater than $105^{\circ} \mathrm{ROM}$ preoperatively had a decrease in ROM postoperatively. Similarly in our study, the severely obese had the poorest ROM while other patients had ROM greater than $105^{\circ}$. Judging based on what was reported by Parsley et al. [20], it is consistent that severely obese patients should have improvement in ROM postoperatively. With respect to the other outcomes scores, the obese patients had similar improvements as compared with the nonobese patients. Our findings agree with those of Nunez et al. [19], who reported that obese patients were not disadvantaged as compared with nonobese patients in terms of improvements in the outcome scores as compared with their baseline.

The true impact of obesity on outcomes of TKA remains elusive as secondary disorders exert a confounding effect on results. Despite the conflicting evidence in the literature, clear relationships have been established between obesity and other comorbidities, such as cardiovascular disease and diabetes mellitus, which in turn could adversely affect outcomes after TKA [12]. TKA reportedly improves function and pain in obese patients [25]. Based on the observations in our study and the literature in general, we believe BMI should not be used as a strong determinant for anticipating postoperative outcomes or exclusion from surgery. Selection of patients should be individualized, and all factors should be considered in their entirety. Given that obesity is a potentially modifiable risk factor, preoperative and postoperative management specifically targeting obese patients should be developed. With the health risks associated with obesity, there could be bias in patient selection in a bid to avoid postoperative complications and negative outcomes. Several of these obese patients may be turned away or sent for weight reduction counseling before surgery. However, weight reduction will continue to be a challenge in these patients as their activity levels are compromised, not just by obesity but also by pain from the OA [25]. Our findings contribute additional information to the current literature and may be extrapolated to aid orthopaedic surgeons in preoperative counseling of obese Asian patients needing a TKA. Although we found no differences in the ROM and outcome scores between nonobese and obese Asian patients undergoing TKAs in the short-term, the long-term durability of the implants remains unknown.

\section{References}

1. Anuurad E, Shiwaku K, Nogi A, Kitajima K, Enkhmaa B, Shimono K, Yamane Y. The new BMI criteria for Asians by the Regional Office for the Western Pacific Region of WHO are suitable for screening of overweight to metabolic syndrome in elder Japanese elder workers. J Occup Health. 2003;45:335-343. 
2. Berend ME, Ritter MA, Hyldahl HC, Meding JB, Redelman R. Implant migration and failure in total knee arthroplasty is related to body mass index and tibial component size. $J$ Arthroplasty. 2008;23(6 suppl 1):104-109.

3. Bin Abd Razak HR, Soon AT, Dhanaraj ID, Tan AH. Incidence of clinically significant venous thromboembolic events in Asian patients undergoing total knee arthroplasty without anticoagulation. J Arthroplasty. 2012;27:1128-1132.

4. Bourne R, Mukhi S, Zhu N, Keresteci M, Marin M. Role of obesity on the risk for total hip or knee arthroplasty. Clin Orthop Relat Res. 2007;465:185-188.

5. Bray GA. Complications of obesity. Ann Intern Med. 1985; 103:1052-1062.

6. Bray GA. Overweight is risking fate: definition, classification, prevalence, and risks. Ann N Y Acad Sci. 1987;499:14-28.

7. Dawson J, Fitzpatrick R, Murray D, Carr A. Questionnaire on the perceptions of patients about total knee replacement. J Bone Joint Surg Br. 1998;80:63-69.

8. Deurenberg-Yap M, Deurenberg P. Is a re-evaluation of WHO body mass index cut-off values needed? The case of Asians in Singapore. Nutr Rev. 2003;61:S80-S87.

9. Dewan A, Bertolusso R, Karastinos A, Conditt M, Noble PC, Parsley BS. Implant durability and knee function after total knee arthroplasty in the morbidly obese patient. J Arthroplasty. 2009; 24(6 suppl):89-94.

10. Dowsey MM, Liew D, Stoney JD, Choong PF. The impact of preoperative obesity on weight change and outcome in total knee replacement: a prospective study of 529 consecutive patients. J Bone Joint Surg Br. 2010;92:513-520.

11. Gandhi R, Razak F, Tso P, Davey JR, Mahomed NN. Asian ethnicity and the prevalence of metabolic syndrome in the osteoarthritic total knee arthroplasty population. J Arthroplasty. 2010;25:416-419.

12. Gillespie GN, Porteous AJ. Obesity and knee arthroplasty. Knee. 2007; 14:81-86.

13. Insall JN, Dorr LD, Scott RD, Scott WN. Rationale of The Knee Society clinical rating system Clin Orthop Relat Res. 1989; 248:13-14.

14. Järvenpää J, Kettunen J, Kröger H, Miettinen H. Obesity may impair the early outcome of total knee arthroplasty. Scand J Surg. 2010;99:45-49.

15. Kurtz S, Ong K, Lau E, Mowat F, Halpern M. Projections of primary and revision hip and knee arthroplasty in the United States from 2005 to 2030. J Bone Joint Surg Am. 2007;89:780785.

16. Lachiewicz AM, Lachiewicz PF. Weight and activity change in overweight and obese patients after primary total knee arthroplasty. J Arthroplasty. 2008;23:33-40.

17. Lara-Esqueda A, Aguilar-Salinas CA, Velazquez-Monroy $\mathrm{O}$, Gómez-Pérez FJ, Rosas-Peralta M, Mehta R, Tapia-Conyer R. The body mass index is a less-sensitive tool for detecting cases with obesity-associated co-morbidities in short stature subjects. Int J Obes Relat Metab Disord. 2004;28:1443-1450.

18. Naylor JM, Harmer AR, Heard RC. Severe other joint disease and obesity independently influence recover after joint replacement surgery: an observational study. Aust J Physiother. 2008;54:5764.

19. Núñez M, Lozano L, Núñez E, Sastre S, Luis Del Val J, Suso S. Good quality of life in severely obese total knee replacement patients: a case control study. Obes Surg. 2011;21: 1203-1208.

20. Parsley BS, Engh GA, Dwyer KA. Preoperative flexion: does it influence postoperative flexion after posterior-cruciate retaining total knee arthroplasty? Clin Orthop Relat Res. 1992;275:204210.

21. Pulido L, Ghadem E, Joshi A, Purtill JJ, Parvizi J. Periprosthetic joint infection: the incidence, timing, and predisposing factors. Clin Orthop Relat Res. 2008;466:1710-1715.

22. Ramachandran A, Snehalatha C. Rising burden of obesity in Asia. J Obes. 2010;2010.pii:868573.

23. Schurman DJ, Bloch DA, Segal MR, Tanner CM. Conventional cemented total hip arthroplasty: assessment of clinical factors associated with revision for mechanical failure. Clin Orthop Relat Res. 1989;240:173-180.

24. Spicer DD, Pomeroy DL, Badenhausen WE, Schaper LA Jr, Curry JI, Suthers KE, Smith MW. Body mass index as a predictor of outcome in total knee replacement. Int Orthop. 2001;25:246249.

25. Stern SH, Insall JN. Total knee arthroplasty in obese patients. J Bone Joint Surg Am. 1990;72:1400-1404.

26. Stevens J, Cai J, Juhaeri, Thun MJ, Wood JL. Evaluation of WHO and NHANES II standards for overweight using mortality rates. J Am Diet Assoc. 2000;100:825-827.

27. Stevens-Lapsley JE, Petterson SC, Mizner RL, Snyder-Mackler L. Impact of body mass index on functional performance after total knee arthroplasty. J Arthroplasty. 2010;25:1104-1109.

28. Stukenborg-Colsman C, Ostermeier S, Windhagen H. [What effect does obesity have on the outcome of total hip and knee arthroplasty: review of the literature][in German]. Orthopade. 2005;34:664-667.

29. Sturmer T, Gunther KP, Brenner H. Obesity, overweight and patterns of osteoarthritis: the Ulm Osteoarthritis Study. J Clin Epidemiol. 2000;53:307-313.

30. Tangtrakulwanich B, Geater AF, Chongsuvivatwong V. Prevalence, patterns, and risk factors of knee osteoarthritis in Thai monks. J Orthop Sci. 2006;11:439-445.

31. Ware JE Jr, Sherbourne CD. The MOS 36-item short-form health survey (SF-36): I. Conceptual framework and item selection. Med Care. 1992;30:473-483.

32. World Health Organization. Obesity: preventing and managing the global epidemic. Report of a WHO consultation. World Health Organ Tech Rep Ser. 2000;894:i-xii, 1-253. 